\title{
DETERMINAN STRUKTUR MODAL PADA SEKTOR KONSTRUKSI BANGUNAN YANG TERCATAT DI BURSA EFEK INDONESIA
}

\author{
Endri \\ Arifin Siagian \\ arief.agian@yahoo.com \\ Magister Manajemen, Fakultas Ekonomi, Universitas Satya Negara Indonesia \\ Jalan Arteri Pondok Indah No.11 Jakarta Selatan
}

\begin{abstract}
This studyaims to analyze the factors that influence the capital structure. The independent variables to be examined are company size, asset structure, profitability, liquidity, company growth, business risk and dividend policy. The population in this study is building construction sector companies which listed in Indonesia Stock Exchange. The samples used are 8 building contruction sector companies which have complete financial report from 2009 to 2013 and engaged in contruction business without through its subsidiary (holding company). The model used in this research is the fixed effects approach. The results show that partially the factors that influence the capital structure are company size, asset structure, profitability and liquidity, whereas company growth, business risk and dividend policy do not influence the capital structure. This study results also show that simultaneously 90,99 percentage the capital structure is influenced by the company size, asset structure, profitability, liquidity, company growth, business risk and dividend policy influence, whereas 9,01 percentage capital structure is influenced by others variable outside research model.
\end{abstract}

Keywords: capital structure, company size, asset structure, profitability, liquidity, company growth, business risk, dividend policy.

\section{PENDAHULUAN}

Pada tahun 2013, Indonesia mengalami penurunan pertumbuhan ekonomi sebesar $0.48 \%$, dimana pada tahun 2012 pertumbuhan ekonomi Indonesia berada di angka $6.26 \%$ dan menurun pada tahun 2013 menjadi 5.78\%. PDB di Indonesia dikonstribusi dari sembilan sektor usaha. Sembilan sektor usaha tersebut adalah: (1) Pertanian, Peternakan, Kehutanan dan Perikanan; (2) Pertambangan dan Penggalian; (3) Industri Pengolahan; (4) Listrik, Gas dan Air Bersih (5) Konstruksi; (6) Perdagangan, Hotel dan Restoran; (7) Pengangkutan dan Komunikasi; (8) Keuangan, Real Estat dan Jasa Perusahaan; serta (9) Jasa-Jasa

Konstruksi merupakan salah satu sektor industriyang memiliki nilaipenting dan strategis bagi pembangunan di suatu negara. Sektor ini juga berperan dalam pengembangan dan peningkatan sektor-sektor lainnya. Pada tahun 2013, PDB Indonesia membukukan angka sebesar Rp. 2.770.345 Miliar dimana sektor konstruksi memberikan kontribusi terhadap PDB sebesar $6,57 \%$, dan merupakan sektor yang mengalami pertumbuhan terbesar keduadi Indonesia. Pembangunan infrastrukturdi bawah program MP3EI yang bertujuan untuk 
mempercepat dan memperkuat pembangunan ekonomi menyebabkan jasa konstruksi akan terus meningkat baik dari sektor swasta maupun pemerintah. Berdasarkan tren industri,sektor ini diperkirakan akanterus tumbuh mencapai 10\%-15\% dalamjangka pendeksampai dengan tahun 2015dan dalamjangka panjanghingga2020-2025.

Struktur modal merupakan salah satu faktor yang dapat menentukan nilai perusahaan, karena struktur modal berkaitan dengan keputusan pendanaan dimana sumber dana yang digunakan baik dari utang ataupun ekuitas akan mempengaruhi nilai perusahaan. Struktur modal dipengaruhi oleh beberapa faktor. Beberapa penelitian mengenai struktur modal telah menjelaskan bagaimana faktor-faktor tersebut dapat mempengaruhi struktur modal.

Margaretha dan Ramadhan (2010) melakukan penelitian di industri manufaktur di Bursa Efek Indonesia dimana ukuran perusahaan, asset berwujud, profitabilitas, likuiditas, pertumbuhan perusahaan dan umur perusahaan dapat mempengaruhi struktur modal. Murhadi (2011) menjelaskan bahwa faktor yang menentukan kebijakan utang pada perusahaanperusahaan yang bergerak pada sektor pertambangan di negara-negara ASEAN adalah profitabilitas, ukuran perusahaan, asset tangibility dan tingkat pertumbuhan.

Faktor lainnya yang dapat mempengaruhi struktur modal diantaranya adalah risiko bisnis serta kebijakan dividen perusahaan. Hasil penelitian yang dilakukan oleh Ferdiansya dan Isnurhadi (2013) pada perusahaan pertambangan di Bursa Efek Indonesia bahwa risiko bisnis berpengaruh positif dan signifikan terhadap struktur modal. Hasil studi lainnya dilakukan oleh Hamidi dan Hariyani (2013) pada perusahaan sektor farmasi di Bursa Efek Indonesia bahwa dividen tunai memiliki pengaruh siginifikan dan negatif terhadap struktur modalperusahaan.

Studi ini bertujuan untuk mengestimasi faktor-faktor apakah yang dapat mempengaruhi struktur modal seperti ukuran perusahaan, struktur aktiva, profitabilitas, likuiditas, pertumbuhan perusahaan, risiko bisnis dan kebijakan dividen.

\section{Perumusan Masalah}

1. Apakah ukuran perusahaan secara parsial berpengaruh terhadap struktur modal?

2. Apakah struktur aktiva secara parsial berpengaruh terhadap struktur modal?

3. Apakah profitabilitas secara parsial berpengaruh terhadap struktur modal?

4. Apakah likuiditas secara parsial berpengaruh terhadap struktur modal?

5. Apakah pertumbuhan perusahaan secara parsial berpengaruh terhadap struktur modal?

6. Apakah risiko bisnis secara parsial berpengaruh terhadap struktur modal?

7. Apakah kebijakan dividen secara parsial berpengaruh terhadap struktur modal?

8. Apakah ukuran perusahaan, struktur aktiva, profitabilitas, likuiditas, pertumbuhan perusahaan, risiko bisnisdan kebijakan dividensecara bersama-sama berpengaruh terhadap struktur modal?

\section{Tujuan Penelitian}

1. Mengestimasi pengaruh ukuran perusahaan secara parsial terhadap struktur modal pada perusahaan-perusahaan sektor konstruksi bangunan di Bursa Efek Indonesia selama periode 2009-2013.

2. Mengestimasi pengaruh struktur aktiva secara parsial terhadap struktur modal pada perusahaan-perusahaan sektor konstruksi bangunan di Bursa Efek Indonesia selama periode 2009-2013.

3. Mengestimasi pengaruh profitabilitas secara parsial terhadap struktur modal pada perusahaan-perusahaan sektor konstruksi bangunan di Bursa Efek Indonesia selama periode 2009-2013. 


\section{Uji Hipotesis}

\section{Uji Signifikansi Variabel Bebas (Uji-T)}

Uji-T digunakan untuk menguji pengaruh variabel independen secara parsial terhadap variabel dependen. Kriterianya uji-t sebagai berikut:

a. Jika probabilitas $(p$-value $)<$ taraf nyata $(\alpha)$, maka Ho ditolak, ini berarti variabel ukuran perusahaan, struktur aktiva, profitabilitas, likuiditas, pertumbuhan perusahaan, risiko bisnis dan dividen secara parsial berpengaruh terhadap variabel struktur modal.

b. Jikaprobabilitas ( $p$-value $)>$ taraf nyata $(\alpha)$, maka Ho diterima, ini berarti variabel ukuran perusahaan, struktur aktiva, profitabilitas, likuiditas, pertumbuhan perusahaan, risiko bisnis dan dividen secara parsial tidak berpengaruh terhadap variabel struktur modal.

\section{Uji Signifikansi Model (Uji-F)}

Uji-F digunakan untuk menguji pengaruh variabel independen, secara bersama-sama atau simultan terhadap variabel dependen. Kriteria uji-F sebagai berikut:

a. Jika probabilitas (p-value) $>$ taraf nyata $(\alpha)$, maka Ho diterima berarti variabel ukuran perusahaan, struktur aktiva, profitabilitas, likuiditas, pertumbuhan perusahaan, risiko bisnis dan dividen secara bersama-sama tidak berpengaruh terhadap variabel struktur modal.

b. Jika probabilitas $(p$-value $)<$ taraf nyata $(\alpha)$, maka Ho ditolak berarti variabel ukuran perusahaan, struktur aktiva, profitabilitas, likuiditas, pertumbuhan perusahaan, risiko bisnis dan dividen secara bersama-sama berpengaruh terhadap variabel struktur modal.

\section{Uji Koefisien Determinasi $\left(\mathbf{R}^{2}\right)$}

Uji $\mathrm{R}^{2}$ digunakan untuk mengetahui kesesuaian hubungan antara variabel independen dengan variabel dependen dalam suatu persamaan regresi. Koefisien determinasi menggambarkan besarnya pengaruh variabel ukuran perusahaan, struktur aktiva, profitabilitas, likuiditas, pertumbuhan perusahaan, risiko bisnis dan kebijakan dividen terhadap variabel struktur modal atau untuk meneliti derajat keeratan hubungan antar variabel.

\section{PEMBAHASAN}

\section{Pooling Least Square vs Fixed Effect Model (Uji CHOW)}

Indikator yang digunakan pada uji ini adalah F-Statistik. Berikut ini merupakan komponen-komponen untuk perhitungan uji chow yang diperoleh dari hasil regresi kedua model tersebut:

Tabel 1

Komponen Perhitungan Uji Chow

\begin{tabular}{|l|c|}
\hline \multicolumn{1}{|c|}{ Komponen Chow Test } & Nilai \\
\hline Restricted Residual Sum Square (RRSS) & 76.12344 \\
\hline Unrestricted Residual Sum Square (URSS) & 15.70859 \\
\hline Jumlah Data Cross Section (N) & 8 \\
\hline Jumlah Data Time Series (T) & 5 \\
\hline Jumlah Variabel Penjelas (K) & 7 \\
\hline
\end{tabular}


Dengan menggunakan rumus uji Chow diatas maka diketahui bahwa Chow (F hitung) adalah 13,74. Dengan tingkat keyakinan $95 \%, \alpha=5 \%$, df1 $=\mathrm{N}-1(8-1=7)$ dan df2 = NT-N$\mathrm{K}(40-8-7=25)$, sehingga hasil yang diperoleh pada $\mathrm{F}$ tabel adalah 2,40 . Oleh karenanya dapat dilihat bahwa F hitung $>\mathrm{F}$ tabel $(13,74>2,40)$, sehingga Ho ditolak. Dengan demikian, metode yang dipilih yaitu metode Fixed Effect.

\section{Fixed Effect Model vs Random Effect Model (Uji Haussman)}

Indikator yang digunakan adalah dengan membandingkan nilai prob.chi-square statistic dengan taraf nyata 5\%. Berikut ini adalah hasil pengujian uji haussman:

\section{Tabel 2}

Hasil Uji Haussman

Correlated Random Effects - Hausman Test

Equation: Untitled

Test cross-section random effects

\begin{tabular}{llrl}
\hline \hline Test Summary & $\begin{array}{l}\text { Chi-Sq. } \\
\text { Statistic Chi-Sq. d.f. }\end{array}$ & Prob. \\
\hline \hline Cross-section random & 72.055068 & 7 & 0.0000 \\
\hline \hline
\end{tabular}

Berdasarkan hasil pengujian pada tabel 2, dapat dilihat bahwa nilai prob.chi-square statistic sebesar 0,000 , sehingga dapat diketahui bahwa nilai prob.chi-square statistic $<$ taraf nyata $(\alpha)(0,000<0,05)$, sehingga HO ditolak. Dengan demikian, metode yang dipilih yaitu metode Fixed Effect.

\section{Uji Heteroskedatisitas}

Hasil uji park dalam penelitian ini dapat dilihat pada tabel 3. Berdasarkan hasil pengujian tersebut, dapat dilihat bahwa variabel independen menghasilkan nilai $\mathrm{P}$ value (sig) diatas taraf nyata 0.05 , sehingga dapat disimpulkan hipotesis adanya heteroskedasitas pada model ditolak.

\section{Tabel 3}

\section{Hasil Uji Park}

Dependent Variable: LOG(RES2)

Method: Panel Least Squares

Date: 01/13/15 Time: 22:55

Sample: 20092013

Periods included: 5

Cross-sections included: 8

Total panel (balanced) observations: 40

\begin{tabular}{ccccc}
\hline \hline Variable & Coefficient & Std. Error & t-Statistic & Prob. \\
\hline \hline $\mathrm{C}$ & 9.563043 & 22.30372 & 0.428764 & 0.6718
\end{tabular}




\begin{tabular}{crrrr} 
SIZE & -0.659088 & 0.847987 & -0.777238 & 0.4443 \\
FAR & -2.546541 & 9.167624 & -0.277776 & 0.7835 \\
ROE & -5.972307 & 5.528709 & -1.080235 & 0.2903 \\
CR & 0.336743 & 1.820715 & 0.184951 & 0.8548 \\
GROWTH & 2.343835 & 1.555188 & 1.507107 & 0.1443 \\
RISK & -0.020483 & 0.012981 & -1.577999 & 0.1271 \\
DPR & 1.716578 & 0.866894 & 1.980147 & 0.0588 \\
\hline
\end{tabular}

Effects Specification

Cross-section fixed (dummy variables)

\begin{tabular}{lrlr}
\hline \hline R-squared & 0.464288 & Mean dependent var & -8.015470 \\
Adjusted R-squared & 0.164290 & S.D. dependent var & 1.664373 \\
S.E. of regression & 1.521523 & Akaike info criterion & 3.957297 \\
Sum squared resid & 57.87579 & Schwarz criterion & 4.590626 \\
Log likelihood & -64.14593 & Hannan-Quinn criter. & 4.186289 \\
F-statistic & 1.547635 & Durbin-Watson stat & 2.810218 \\
Prob(F-statistic) & 0.165246 & & \\
\hline
\end{tabular}

\section{Model Regresi Data Panel}

Berdasarkan hasil pengujian model data panel di atas, dapat dilihat bahwa model yang layak digunakan dalam penelitian ini adalah Fixed Effect Approach. Tabel 4 dibawah ini merupakan hasil regresi menggunakan Fixed Effect Approach:

Tabel 4

Hasil Regresi Fixed Effect Approach

Dependent Variable: DER?

Method: Pooled Least Squares

Date: 01/21/15 Time: 22:01

Sample: 20092013

Included observations: 5

Cross-sections included: 8

Total pool (balanced) observations: 40

\begin{tabular}{crrrr}
\hline \hline Variable & Coefficient & Std. Error & t-Statistic & Prob. \\
\hline \hline C & 45.46837 & 11.61977 & 3.913019 & 0.0006 \\
SIZE? & -1.464194 & 0.441783 & -3.314280 & 0.0028 \\
FAR? & -11.53670 & 4.776138 & -2.415487 & 0.0234 \\
ROE? & 8.968332 & 2.880340 & 3.113636 & 0.0046 \\
CR? & -3.065190 & 0.948554 & -3.231435 & 0.0034 \\
GROWTH? & 0.849092 & 0.810220 & 1.047977 & 0.3047 \\
RISK? & 0.001404 & 0.006763 & 0.207686 & 0.8372 \\
DPR? & 0.736934 & 0.451634 & 1.631707 & 0.1153 \\
Fixed Effects & & & & \\
(Cross) & & & &
\end{tabular}




$\begin{array}{lr}\text { _ACST--C } & -20.25771 \\ \text { _ADHI--C } & 5.112281 \\ \text { _DGKI--C } & 1.870286 \\ \text { _NRCA--C } & -0.984601 \\ \text { _PTPP--C } & 4.408549 \\ \text { _TOTL--C } & 0.591459 \\ \text { _WSKT--C } & 5.478625 \\ \text { _WIKA--C } & 3.781113\end{array}$

Effects Specification

Cross-section fixed (dummy variables)

\begin{tabular}{lrll}
\hline \hline R-squared & 0.909990 & Mean dependent var & 3.115472 \\
Adjusted R-squared & 0.859584 & S.D. dependent var & 2.115391 \\
S.E. of regression & 0.792681 & Akaike info criterion & 2.653205 \\
Sum squared resid & 15.70859 & Schwarz criterion & 3.286535 \\
Log likelihood & -38.06410 & Hannan-Quinn criter. & 2.882197 \\
F-statistic & 18.05333 & Durbin-Watson stat & 1.475669 \\
Prob(F-statistic) & 0.000000 & & \\
\hline \hline
\end{tabular}

\section{Uji Hipotesis}

\section{Uji Signifikansi Variabel Bebas (Uji-T)}

\section{Ukuran Perusahaan dan Struktur Modal.}

Dari hasil regresi pada tabel 4 didapatkan bahwa variabel ukuran perusahaan (size) memiliki probabilitas $<0.05(0.0028<0.05)$, dengan koefisien bernilai -1.464194 . Ini berarti bahwa ukuran perusahaan secara parsial berpengaruh terhadap struktur modal pada perusahaan-perusahaan sektor konstruksi bangunan di Bursa Efek Indonesia selama periode 2009-2013. Hubungan yang terjadi antara ukuran perusahaan dengan struktur modal adalah negatif, sehingga semakin besar ukuran perusahaan maka semakin kecil rasio DER perusahaan.

Hasil penelitian sejalan dengan Pecking Order Theory dimana perusahaan lebih menyukai pendanaan melalui internal financing (laba hasil operasi) terlebih dahulu sebelum menggunakan utang, namun tidak didukung oleh hasil penelitian sebelumnya yang dilakukan oleh Nuswandari (2013), Firnanti (2011), Widjaja (2013), Endang Utami (2009) serta Joni dan Lina (2010) yang menyatakan bahwa ukuran perusahaan tidak memiliki pengaruh terhadap struktur modal., namu

\section{Struktur Aktiva dan Struktur Modal.}

Dari hasil regresi pada tabel 4 didapatkan bahwa variabel struktur aktiva $(F A R)$ memiliki probabilitas $<0.05(0.0234<0,05)$, dengan koefisien bernilai -11.53670 . Ini berarti bahwa truktur aktiva secara parsial berpengaruh terhadap struktur modal pada perusahaanperusahaan sektor konstruksi bangunan di Bursa Efek Indonesia selama periode 2009-2013. Hubungan yang terjadi antara struktur aktiva dengan struktur modal adalah negatif, sehingga semakin besar struktur aktiva perusahaan maka semakin kecil rasio DER perusahaan. 
Hasil penelitian ini didukung oleh hasil penelitian sebelumnya yang dilakukan oleh Widjaja (2013) yang menyatakan bahwa struktur aktiva berpengaruh negatif dan signifikan terhadap struktur modal, namun tidak didukung oleh hasil penelitian yang dilakukan oleh Joni dan Lina (2010) yang menyatakan bahwa struktur aktiva memiliki pengaruh positif terhadap struktur modal. Hasil penelitian ini juga sejalan dengan Pecking Order Theory dimana perusahaan lebih menyukai pendanaan melalui internal financing (laba hasil operasi) terlebih dahulu sebelum menggunakan utang.

\section{Profitabilitas dan Struktur Modal}

Dari hasil regresi pada tabel 4 didapatkan bahwa variabel profitabilitas (ROE) memiliki probabilitas $<0.05(0.0046<0,05)$, dengan koefisien bernilai 8.968332. Ini berarti bahwa profitabilitas secara parsial berpengaruh terhadap struktur modal pada perusahaan-perusahaan sektor konstruksi bangunan di Bursa Efek Indonesia selama periode 2009-2013. Hubungan yang terjadi antara profitabilitas dengan struktur modal adalah positif, sehingga semakin besar profitabilitas perusahaan maka semakin besar pula rasio DER perusahaan.

Hasil penelitian ini tidak sejalan dengan Pecking Order Theory bahwa jika perusahaan mempunyai profit yang tinggi, maka perusahaan cenderung akan menggunakan utang dalam jumlah rendah. Hasil penelitian ini juga tidak didukung oleh hasil penelitian sebelumnya yang dilakukan oleh Nuswandari (2013), Widjaja (2013), Joni dan Lina (2010) serta Firnanti (2011) yang menyatakan bahwa profitabilitas memiliki pengaruh negatif terhadap struktur modal.

\section{Likuiditas dan Struktur Modal}

Dari hasil regresi pada tabel 4 didapatkan bahwa variabel likuiditas $(C R)$ memiliki probabilitas $<0.05(0.0034<0,05)$, dengan koefisien bernilai 3.065190. Ini berarti bahwa likuiditas secara parsial berpengaruh terhadap struktur modal pada perusahaan-perusahaan sektor konstruksi bangunan di Bursa Efek Indonesia selama periode 2009-2013. Hubungan yang terjadi antara likuiditas dengan struktur modal adalah negatif, sehingga semakin besar likuiditas perusahaan maka semakin kecil rasio DER perusahaan.

Hal penelitian ini sejalan dengan Pecking Order Theory, dimana perusahaan yang mempunyai likuiditas yang semakin tinggi, maka cenderung untuk menggunakan ekuitas terlebih dahulu sebagai sumber dana, sehingga likuiditas memiliki hubungan yang negatif terhadap struktur modal. Hasil penelitian ini didukung oleh hasil penelitian sebelumnya yang dilakukan oleh Widjaja (2013) serta Ferdiansya dan Isnurhadi (2010) yang menyatakan bahwa likuiditas memiliki pengaruh negatif terhadap struktur modal.

\section{Pertumbuhan Perusahaan dan Struktur Modal}

Dari hasil regresi pada tabel 4 didapatkan bahwa pertumbuhan perusahaan (growth) memiliki probabilitas > $0.05(0.3047>0,05)$. Ini berarti bahwa pertumbuhan perusahaan secara parsial tidak berpengaruh terhadap struktur modal pada perusahaan-perusahaan sektor konstruksi bangunan di Bursa Efek Indonesia selama periode 2009-2013.

Hasil penelitian menggambarkan bahwa selama periode 2009-2013, pertumbuhan perusahaan tidak mempengaruhi keputusan struktur modal. Ini dikarenakan keputusan pendanaan lebih disebabkan karena ekspansi usaha dan prospek perusahaan konstruksi sehingga beberapa emiten perusahaan konstruksi bangunan meningkatkan anggaran belanja modal (capital expenditure). Hasil penelitian ini didukung oleh hasil penelitian yang dilakukan oleh Utami (2009) yang menyatakan bahwa tingkat pertumbuhan tidak memiliki pengaruh terhadap struktur modal, namun tidak didukung oleh hasil penelitian sebelumnya yang dilakukan oleh Joni dan Lina (2010) serta Firnanti (2011) yang menyatakan bahwa pertumbuhan perusahaan memiliki pengaruh terhadap struktur modal. 


\section{Risiko Bisnis dan Struktur Modal}

Dari hasil regresi pada tabel 4 didapatkan bahwa variabel risiko bisnis (risk) memiliki probabilitas $>0.05(0.8372>0,05)$. Ini berarti bahwa risiko bisnis secara parsial tidak berpengaruh terhadap struktur modal pada perusahaan-perusahaan sektor konstruksi bangunan di Bursa Efek Indonesia selama periode 2009-2013.

Hasil penelitian ini meng-gambarkan bahwa secara umum risiko yang dialami perusahaan konstruksi seperti risiko kredit, risiko nilai tukar, risiko tingkat suku bunga, risiko kenaikan harga dan ketersediaan bahan baku serta risiko likuiditas dapat dihindarkan dengan pengelolaan dan manajemen risiko yang baik. Seperti penggunaan mata uang rupiah untuk menghindarkan risiko valas, monitoring suku bunga yang ketat, hingga adanya informasi dari pemasok di dalam pembuatan rencana anggaran biaya untuk suatu proyek sehingga risiko kenaikan harga bahan baku dapat dihindarkan.

Hasil penelitian ini didukung oleh hasil penelitian sebelumnya yang dilakukan oleh Utami (2009), Joni dan Lina (2010) serta Firnanti (2011) yang menyatakan bahwa risiko bisnis tidak memiliki pengaruh terhadap struktur modal, namun tidak didukung oleh hasil penelitian yang dilakukan oleh Ferdiansyah dan Isnurhadi (2013) yang menyatakan bahwa risiko bisnis memiliki pengaruh terhadap struktur modal.

\section{Kebijakan Dividen dan Struktur Modal}

Dari hasil regresi pada tabel 4 didapatkan bahwa variabel kebijakan dividen (dividend) memiliki probabilitas > $0.05(0.1153>0,05)$. Ini berarti bahwa Kebijakan dividen secara parsial tidak berpengaruh terhadap struktur modal pada perusahaan-perusahaan sektor konstruksi bangunan di Bursa Efek Indonesia selama periode 2009-2013.

Hasil penelitian ini disebabkan karena beberapa perusahaan konstruksi sudah berada pada kondisi perusahaan yang mature dimana perusahaan selalu berusaha untuk memperhatikan hak-hak pemegang saham. Selain itu, dengan pertimbangan ekspansi usaha, ketersediaan cadangan kas, kebutuhan belanja modal dan kondisi keuangan sehingga beberapa perusahaan lainnya tidak membagikan dividen mempengaruhi pembayaran dividen kas selama periode 2009-2013.

Hasil penelitian ini didukung oleh hasil penelitian sebelumnya yang dilakukan oleh Joni dan Lina (2010) yang menyatakan bahwa kebijakan deviden tidak memiliki pengaruh terhadap struktur modal. Namun, hasil penelitian ini tidak didukung oleh hasil penelitian yang dilakukan oleh Hamidi \& Hariyani (2013) yang menyatakan bahwa dividen tunai memiliki pengaruh negatif terhadap struktur modal.

\section{Uji Signifikansi Model (Uji-F)}

Pada output regresi dalam tabel 4 diketahui bahwa nilai prob $\mathrm{F}<0,05(0,000000<0,05)$, artinya variabel ukuran perusahaan (size), struktur aktiva $(F A R)$, profitabilitas (ROE), likuiditas $(C R)$, pertumbuhan perusahaan (growth), risiko bisnis (risk) dan kebijakan dividen (dividend) secara bersama-sama berpengaruh terhadap struktur modal (DER) pada perusahaan-perusahaan sektor konstruksi bangunan di Bursa Efek Indonesia selama periode 2009-2013.

\section{Uji Korelasi Determinasi $\left(\mathbf{R}^{\mathbf{2}}\right)$}

Pada output regresi dalam tabel 4 , nilai $\mathrm{R}^{2}$ menunjukkan nilai 0.909990 , ini berarti bahwa 90,999\% variabel struktur modal (DER) dipengaruhi oleh variabel ukuran perusahaan (size), struktur aktiva $(F A R)$, profitabilitas $(R O E)$, likuiditas $(C R)$, pertumbuhan perusahaan (growth), risiko bisnis (risk) dan kebijakan dividen (dividend), sedangkan 9,001\% lainnya 
dipengaruhi oleh variabel lain di luar model regresi seperti umur perusahaan, arus kas bebas, kebijakan managerial, time interest earned, investasi, non debt tax shield dan lain-lain.

\section{Persamaan Regresi Data Panel}

Berdasarkan persamaan regresi pada tabel 4, maka dapat diketahui persamaan regresi untuk masing-masing perusahaan konstruksi bangunan di Bursa Efek Indonesia periode 20092013 adalah sebagai berikut:

1. PT. Acset Internusa Tbk (ACST)

DER_ACST $=-20.258+45.468-1.464$ Size_ACST $-11.537 \mathrm{FAR} \_$ACST $+8.968 \mathrm{ROE} \_$ACST 3.065CR_ACST + 0.849Growth_ACST + 0.001Risk_ACST + 0.737DPR_ACST

2. PT. Adhi Karya (Persero) Tbk (ADHI)

DER_ADHI $=5.112+45.468-1.464$ Size_ADHI $-11.537 \mathrm{FAR} \_A D H I+8.968 \mathrm{ROE} \_$ADHI 3.065CR_ADHI + 0.849Growth_ADHI + 0.001Risk_ADHI + 0.737DPR_ADHI

3. PT. Nusa Konstruksi Enjiniring Tbk (DGIK)

DER_DGKI $=1.870+45.468-1.464$ Size_DGKI $-11.537 \mathrm{FAR} \_$DGKI $+8.968 \mathrm{ROE} \_$DGKI 3.065CR_DGKI + 0.849Growth_DGKI + 0.001Risk_DGKI + 0.737DPR_DGKI

4. PT. Nusa Raya Cipta Tbk (NRCA)

DER_NRCA $=-0.985+45.468-1.464$ Size_NRCA $-11.537 \mathrm{FAR} \_\mathrm{NRCA}+8.968 \mathrm{ROE} \_\mathrm{NRCA}-$ 3.065CR_NRCA + 0.849Growth_NRCA + 0.001Risk_NRCA + 0.737DPR_NRCA

5. PT. Pembangunan Perumahan (Persero) Tbk (PTPP) DER_PTPP $=4.409+45.468-1.464$ Size_PTPP $-11.537 \mathrm{FAR} \_P T P P+8.968 R O E \_$_PTP 3.065CR_PTPP + 0.849Growth_PTPP + 0.001Risk_PTPP + 0.737*DPR_PTPP

6. PT. Total Bangun Persada Tbk (TOTL)

$\mathrm{DER}_{\text {_totL }}=0.591+45.468-1.464 \mathrm{Size}_{-}$тотL $-11.537 \mathrm{FAR} \_$тотL $+8.968 \mathrm{ROE} \_$тотL 3.065CR_tотL +0.849 Growth_tотL +0.001 Risk_toтL $+0.737 \mathrm{DPR}$ _тотL

7. PT. Waskita Karya (Persero) Tbk (WSKT)

DER_wSKT $=5.479+45.468-1.464$ Size_wsKT $-11.537 \mathrm{FAR} \_$wSKT $+8.968 \mathrm{ROE} \_$wSKT 3.065CR_wSKT + 0.849Growth_wSKT +0.001 Risk_wSKT $+0.737 \mathrm{DPR} \_w s K T$

8. PT. Wijaya Karya (Persero) Tbk (WIKA)

DER_WIKA $=3.781+45.468-1.464$ Size_WIKA $-11.537 \mathrm{FAR} \_$WIKA $+8.968 \mathrm{ROE} \_$WIKA 3.065CR_wIKA + 0.849Growth_wIKA + 0.001Risk_wIKA + 0.737DPR_wIKA

\section{PENUTUP}

\section{Kesimpulan}

Berdasarkan hasil pengujian pada perusahaan sektor konstruksi bangunan di Bursa Efek Indonesia periode 2009-2013 yang telah dilakukan menggunakan model regresi panel data, maka dapat ditarik kesimpulan sebagai berikut :

1. Ukuran perusahaan secara parsial berpengaruh terhadap struktur modal pada perusahaanperusahaan sektor konstruksi bangunan di Bursa Efek Indonesia selama periode 20092013. Hubungan yang terjadi antara ukuran perusahaan dengan struktur modal adalah negatif, sehingga semakin besar ukuran perusahaan maka semakin kecil rasio DER perusahaan.

2. Struktur aktiva secara parsial berpengaruh terhadap struktur modal pada perusahaanperusahaan sektor konstruksi bangunan di Bursa Efek Indonesia selama periode 20092013. Hubungan yang terjadi antara struktur aktiva dengan struktur modal adalah negatif, 
sehingga semakin besar struktur aktiva perusahaan maka semakin kecil rasio DER perusahaan.

3. Profitabilitas secara parsial berpengaruh terhadap struktur modal pada perusahaanperusahaan sektor konstruksi bangunan di Bursa Efek Indonesia selama periode 20092013. Hubungan yang terjadi antara profitabilitas dengan struktur modal adalah positif, sehingga semakin besar profitabilitas perusahaan maka semakin besar pula rasio DER perusahaan.

4. Likuiditas secara parsial berpengaruh terhadap struktur modal pada perusahaanperusahaan sektor konstruksi bangunan di Bursa Efek Indonesia selama periode 20092013. Hubungan yang terjadi antara likuiditas dengan struktur modal adalah negatif, sehingga semakin besar likuiditas perusahaan maka semakin kecil rasio DER perusahaan.

5. Pertumbuhan perusahaan secara parsial tidak berpengaruh terhadap struktur modal pada perusahaan-perusahaan sektor konstruksi bangunan di Bursa Efek Indonesia selama periode 2009-2013.

6. Risiko bisnis secara parsial tidak berpengaruh terhadap struktur modal pada perusahaanperusahaan sektor konstruksi bangunan di Bursa Efek Indonesia selama periode 20092013.

7. Kebijakan dividen secara parsial tidak berpengaruh terhadap struktur modal pada perusahaan-perusahaan sektor konstruksi bangunan di Bursa Efek Indonesia selama periode 2009-2013.

8. Ukuran perusahaan, struktur aktiva, profitabilitas, likuiditas, pertumbuhan perusahaan, risiko bisnisdan kebijakan dividensecara bersama-sama berpengaruh terhadap struktur modal pada perusahaan-perusahaan sektor konstruksi bangunan di Bursa Efek Indonesia selama periode 2009-2013.

\section{Saran}

Beberapa saran yang dapat diberikan penulis antara lain :

1. Terkait dengan hasil penelitian ini, bagi perusahaan, investor serta kreditor diharapkan dapat mempertimbangkan faktor ukuran perusahaan dalam mengambil keputusan struktur modal. Hal ini ditunjukan oleh adanya pengaruh terhadap struktur modal pada perusahaan-perusahaan sektor konstruksi bangunan di Bursa Efek Indonesia selama periode 2009-2013.

2. Terkait dengan hasil penelitian ini, bagi perusahaan, investor serta kreditor diharapkan dapat mempertimbangkan faktor struktur aktiva dalam mengambil keputusan struktur modal. Hal ini ditunjukan oleh adanya pengaruh terhadap struktur modal pada perusahaan-perusahaan sektor konstruksi bangunan di Bursa Efek Indonesia selama periode 2009-2013.

3. Terkait dengan hasil penelitian ini, bagi perusahaan, investor serta kreditor diharapkan dapat mempertimbangkan faktor profitabilitas dalam mengambil keputusan struktur modal. Hal ini ditunjukan oleh adanya pengaruh terhadap struktur modal pada perusahaan-perusahaan sektor konstruksi bangunan di Bursa Efek Indonesia selama periode 2009-2013.

4. Terkait dengan hasil penelitian ini, bagi perusahaan, investor serta kreditor diharapkan dapat mempertimbangkan faktor likuiditas dalam mengambil keputusan struktur modal. Hal ini ditunjukan oleh adanya pengaruh terhadap struktur modal pada perusahaanperusahaan sektor konstruksi bangunan di Bursa Efek Indonesia selama periode 20092013. 
5. Terkait dengan penelitian ini, bagi peneliti selanjutnya diharapkan dapat melakukan pengujian pada sektor lainnya dengan jangka waktu penelitian yang lebih panjang agar dapat diketahui pengaruh faktor pertumbuhan perusahaan terhadap struktur modal.

6. Terkait dengan penelitian ini, bagi peneliti selanjutnya diharapkan dapat melakukan pengujian pada sektor lainnya dengan jangka waktu penelitian yang lebih panjang agar dapat diketahui pengaruh faktor risiko bisnis terhadap struktur modal.

7. Terkait dengan penelitian ini, bagi peneliti selanjutnya diharapkan dapat melakukan pengujian pada sektor lainnya dengan jangka waktu penelitian yang lebih panjang agar dapat diketahui pengaruh faktor kebijakan dividen terhadap struktur modal.

8. Terkait dengan penelitian ini, bagi peneliti selanjutnya diharapkan dapat melakukan pengujian faktor-faktor yang berpengaruh terhadap struktur modal pada sektor lainnya sehingga dapat mengetahui perbandingan antara beberapa sektor lainnya.

\section{DAFTAR PUSTAKA}

Firnanti (2011). Faktor-Faktor Yang Mempengaruhi Struktur Modal Perusahaan Manufaktur di Bursa Efek Indonesia. Jurnal Bisnis dan Akuntansi, 13, 119-128.

http://demo.tsm.ac.id/JBA/JBA13.2Agustus2011/Faktor-

faktor\%20yang\%20Mempengaruhi\%20Struktur\%20Modal\%20Perusahaan\%20Manuf aktur\%20di\%20Bursa\%20Efek\%20Indonesia.pdf

Ferdiansya \& Isnurhadi (2013). Faktor-Faktor Yang Mempengaruhi Struktur Modal Pada Perusahaan Pertambangan Yang Terdaftar di Bursa Efek Indonesia. Jurnal $\begin{array}{lllll}\text { Manajemen } \quad \text { B Bisnis } & \text { Sriwijaya, }\end{array}$ http://eprints.unsri.ac.id/3494/1/jmbs_vol_11,_no._2_juni_2013_syahril__isnurhadi.pdf.

Hamidi \& Hariyani (2013). Pengaruh Struktur Aset, Return On Asset (ROA), Kebijakan Hutang dan Dividen Tunai Terhadap Struktur Modal. http://fe.budiluhur.ac.id/wpcontent/uploads/2013/10/5aReni-Hariyani-Wildan-Hamidi.pdf

Industrial Trend of Construction (2014). Retrieved from Dun\&Bradstreet Indonesia, PT.

Joni \& Lina (2010). Faktor-Faktor Yang Mempengaruhi Struktur Modal Pada Perusahaan Manufaktur Periode 2005 - 2007. Jurnal Bisnis dan Akuntansi, 12, 81-96. http://www.tsm.ac.id/jba/jba12.2agustus2010/2_artikel_jba12.2agustus2010.pdf.

Kasmir. (2014). Analisis Laporan Keuangan. Jakarta: PT RajaGrafindo Jakarta.

Kusumawijaya. (2011). Pengaruh Struktur Modal dan Pertumbuhan Perusahaan Terhadap Profitabilitas dan Nilai Perusahaan Pada Perusahaan Manufaktur Di Bursa Efek Indonesia. Retrieved from http://www.pps.unud.ac.id/thesis/pdf_thesis/unud-136-193760511-tesis.pdf.

Mahapsari \& Taman (2013). Pengaruh Profitabilitas, Struktur Aktiva dan Pertumbuhan Penjualan Terhadap Harga Saham Dengan Struktur Modal Sebagai Variabel Intervening Pada Perusahaan Manufaktur di Bursa Efek Indonesia. Jurnal Nominal, 2, 137-158. http://portalgaruda.org/?ref=browse\&mod=viewarticle\&article=138054.

Muhardi. (2011). Determinan Struktur Modal: Studi Di Asia Tenggara. Retrieved from http://puslit2.petra.ac.id/ejournal/index.php/man/article/view/18325.

Margaretha \& Ramadhan (2010). Faktor-Faktor Yang Mempengaruhi Struktur Modal Pada Industri Manufaktur di Bursa Efek Indonesia. Jurnal Bisnis dan Akuntansi, 12, 119130. 
http://www.stietrisakti.ac.id/jba/jba12.2agustus2010/5_artikel_jba12.2agustus2010.pdf Safrida (2008). Pengaruh Struktur Modal dan Pertumbuhan Perusahaan Terhadap Nilai Perusahaan Pada Perusahaan Manufaktur di Bursa Efek Jakarta. Retrieved from http://repository.usu.ac.id/bitstream/123456789/4007/1/08e00694.pdf?origin=publicati on detail.

Schweser (2012). Schwesernotes ${ }^{T M} 2013$ CFA Level 1 Book 4: Corporate Finance, Portfolio Management and Equity Investments. United States of America: Kapan, Inc.

Subagyo. (2011). Efektifitas Kebijakan Struktur Modal Dalam Meningkatkan Nilai Perusahaan. Jurnal Bisnis dan Ekonomi (JBE), 18, 59 - 68. http://download.portalgaruda.org/article.php?article=7669\&val=548\&title.

Utami (2009). Faktor-Faktor Yang Mempengaruhi Struktur Modal Perusahaan Manufaktur. Fenomena, 7, 39-47.

http://data.dppm.uii.ac.id/uploads/05\%20utami.pdf.

Widjaja \& Deli (2013). Determinan Struktur Modal Pada Perusahaan Manufaktur di Indonesia. Retrieved fromhttp://e-journal.uajy.ac.id/342/.

www.bps.go.id

www.ekonomi.kompasiana.com

www.idx.co.id

www.indonesianminingservices.com

WWw.minerals.usgs.gov

www.wikipedia.org 